\title{
Study of Knowledge, Attitude and Practice regarding Alcohol among College Students
}

\author{
Gaurav Verma ${ }^{1}$, Darshan Patel $^{2}$ \\ Department of Psychiatry, B.J Medical College, Ahmedabad, Gujarat, India
}

\begin{abstract}
Alcohol consumption is widely prevalent world-wide. It can leads to many physical, mental and social problems. Good knowledge and attitude can leads to change the practice regarding alcohol use and can prevent harm from it.To study the knowledge, attitude and practice among college students a semi-structured questionnaire having thirty nine questions in three sections (knowledge, attitude,practice) was given before educational intervention. 527 graduate students participated in this study. The statistical analysis was done using SPSS version 17. The result of study showed good knowledge attitude and practice with Some prominent myths about alcohol likeBeer is not an alcohol, alcohol improves sleep, potentiate sexual performance,significantly reduces anxiety and depression, and alcohol addiction is a bad habit not psychiatric illness. There is need for more educational intervention to correct the myths regarding alcohol.
\end{abstract}

Keywords: knowledge, Attitude, Practice, Alcohol, Health

\section{Introduction}

Alcohol consumption is common among college going students.26.4\% students consume alcohol and many students know the ill effects of alcohol consumption though, most of them considered it as a part of life style (1). Alcohol influences traffic and results in road accidents, family problem and relationship violence and crime, health and financial problems(2). Knowledge and awareness regarding alcohol can change the attitude and which leads to change in practice.

\section{Aims and Objectives}

1) To study the knowledge, attitude and practice among college students, regarding alcohol use.

2) Improve the knowledge and attitude towards the alcohol use.

\section{Method and Material}

A semi-structured questionnaire was prepared having 39 questions in three section,first section having twenty one questions to assess the knowledge, second section having fifteen questions to assess attitude and third section having three questions to asses practice. 527 B.Com students from a degree college in Ahmedabad participated in study and given to fill above described questionnaire in 15 minute before educational intervention.

\section{Analysis}

The statistical analysis was done using SPSS version 17.

\section{Result}

Students belong to age group of 17-22 years in which around $62 \%$ were female and $37 \%$ were male.All were graduate students (B.COM). Most of students (91.7\%) agreed that positive family history is risk for alcohol, two third(71.9\%) agreed that suicide is more common in alcohol use disorder. $65 \%$ students completely agree that Prohibition of alcohol from country is necessary. There were also misconception like beer is not an alcohol(55.8\%) and alcohol improves sleep $(62 \%)$.Alcohol addiction is bad habit not psychiatric illness(62.4). Only $1.3 \%$ students accepted that they had taken alcohol and someone in family wasalso taking alcohol.

Table 1: Section1 (knowledge)

\begin{tabular}{|c|c|c|c|c|}
\hline S. No & Statement & Agree $\%$ & Disagree $\%$ & Neutral \% \\
\hline 1 & liquer is chemical knows as alcohol & 94.1 & 5.7 & 0.2 \\
\hline 2 & Beer is not alcohol & 55.8 & 43.6 & 0.6 \\
\hline 3 & Family history is risk factor for alcohol addiction & 91.7 & 7.2 & 1.1 \\
\hline 4 & Alcohol improves sleep & 62 & 37.6 & 0.4 \\
\hline 5 & Alcohol potentiate sexual performance & 47.1 & 48.8 & 4.2 \\
\hline 6 & Alcohol significantly reduce anxiety and depression & 56.2 & 43.3 & 0.6 \\
\hline 7 & Suicide is more in person with alcohol use disorder & 71.9 & 27.7 & 0.4 \\
\hline 8 & Early age of onset of alcohol is risk factor for dependence & 87.9 & 11.8 & 0.4 \\
\hline 9 & Alcohol improves physical strength & 28.5 & 70.8 & 0.8 \\
\hline 10 & Alcohol is risk factor for anxiety and depressive disorder & 68.7 & 30.2 & 1.1 \\
\hline 11 & Alcohol de-addiction can be possible by faith healing & 22.4 & 76.7 & 0.9 \\
\hline 12 & Tremors are part of withdrawal symptoms & 68.9 & 29.8 & 1.3 \\
\hline 13 & Alcohol withdrawal can be life threatening condition & 50.7 & 48.6 & 0.8 \\
\hline 14 & Alcohol intake increase risk of heart attack & 87.2 & 21.8 & 0.9 \\
\hline 15 & Intake of sleeping pills increase the risk of accident & 19 & 0.8 \\
\hline
\end{tabular}

Volume 6 Issue 7, July 2017 www.ijsr.net 


\section{International Journal of Science and Research (IJSR) \\ ISSN (Online): 2319-7064}

Index Copernicus Value (2015): 78.96 | Impact Factor (2015): 6.391

\begin{tabular}{|l|c|c|c|c|}
\hline 16 & Effect of alcohol is more in female than male even amount of consumption is same & 80.3 & 19.2 & 0.6 \\
\hline 17 & Consumption of alcohol during pregnancy increase risk of MR in child & 78.9 & 19.5 & 1.5 \\
\hline 18 & Alcohol consumption leads to early death & 92 & 7.8 & 0.2 \\
\hline 19 & 'Lattho' is methyl alcohol & 83.3 & 15.4 & 1.3 \\
\hline 20 & Intake of 'lattho' causes blindness or death & 86.3 & 12.5 & 1.1 \\
\hline 21 & Alcohol consumption leads to vitamin deficiency & 87.5 & 12.5 & 0 \\
\hline
\end{tabular}

Table 2: Section 2 (attitude)

\begin{tabular}{|r|c|c|c|c|c|c|c|}
\hline S. & statement & Totally & Disagree & Neutral & Agree & Totally & No \\
No & & disagree $\%$ & $\%$ & $\%$ & $\%$ & agree $\%$ & answer $\%$ \\
\hline 1 & Alcohol addiction is bad habit not the psychiatric illness & 5.1 & 2.8 & 2.7 & 26.6 & 62.4 & 0.4 \\
\hline 2 & Prohibition of alcohol in country is necessary & 4.4 & 5.7 & 9.3 & 14.6 & 65.1 & 0.9 \\
\hline 3 & Alcohol de-addiction can not possible in addicted person & 15.2 & 33.4 & 15.4 & 17.6 & 17.6 & 0.8 \\
\hline 4 & Female should not take alcohol & 10.1 & 8.2 & 7.6 & 24.5 & 48.8 & 9 \\
\hline 5 & Person himself is responsible for failure of de-addiction & 7.2 & 10.1 & 16.3 & 24.9 & 41.6 & 0 \\
\hline 6 & Alcohol is medicine & 31.1 & 20.7 & 20.1 & 16.7 & 11.4 & 0 \\
\hline 7 & Alcohol addiction is sign of weak mind & 7.4 & 10.1 & 13.7 & 36.1 & 31.9 & 0.9 \\
\hline 8 & Once alcohol addiction occurred it is difficult to control intake of & 9.5 & 17.8 & 18.2 & 25.4 & 28.1 & 0.9 \\
\hline 9 & amount of alcohol & & & & & & \\
\hline
\end{tabular}

Table 3: Section 3 (practice)

\begin{tabular}{|c|c|c|c|c|}
\hline \multicolumn{5}{|l|}{ Statement } \\
\hline Did u ever took alcohol & $\begin{array}{l}\text { Yes } \\
1.3 \%\end{array}$ & \multicolumn{2}{|c|}{$\begin{array}{c}\text { No } \\
83.7 \% \\
\end{array}$} & $\begin{array}{c}\text { No answer } \\
15 \%\end{array}$ \\
\hline If yes, then when & $\begin{array}{c}<1 \text { month } \\
0.4 \%\end{array}$ & $\begin{array}{c}<1 \text { year } \\
0.6 \%\end{array}$ & $\begin{array}{c}>1 \text { year } \\
0.2 \%\end{array}$ & $\begin{array}{c}\text { No answer } \\
98.9 \%\end{array}$ \\
\hline Does anyone in your family has alcohol addiction & $\begin{array}{l}\text { Yes } \\
1.3 \%\end{array}$ & \multicolumn{2}{|c|}{$\begin{array}{c}\text { No } \\
80.6 \%\end{array}$} & $\begin{array}{c}\text { No answer } \\
18 \%\end{array}$ \\
\hline
\end{tabular}

\section{Discussion}

Majority of graduate students were in the age group of 17-22 years. This study showing that alcohol use is uncommon in college going students in contrast to study in Banglore where it was reported that alcohol use was fairly commonamong undergraduate college students(3). This may be due to good knowledge and prohibition of alcohol in Gujarat by government. Majority of students $(62.4 \%)$ totally agree that alcohol addiction is part of bad habit not the psychiatry illness, this also similar to other study in which majority of students considered it as part of life style(1). Only $1.3 \%$ students had tried alcohol which is contrast to other study (1), this may again due to good knowledge and favourable attitude towards alcohol. Prohibition of alcohol in Gujarat state may be contributing to these contrast findings.

\section{Conclusion}

Knowledge, attitude and practice is good in college students of Ahmedabad. Although there were some myths related to alcohol need to be corrected by frequent education interventions. Such educational interventions will improve knowledge which will leads to change of attitude and practice.

\section{Limitation of study}

Post educational intervention knowledge, attitude and practice was not assessed.Small sample size.

\section{Acknowledgement}

I express my gratitude to my teacher Dr. G. K Vanker, Department of Psychiatry, Civil Hospital, Ahmedabad, forguidance and helpful criticism during the study. I acknowledge help from, Dr.GauttamPrajapati and Dr.Tejas Patel incourse of study.

\section{References}

[1] Deepak Daniel ,DevishriShetty , GreeshmaJilson Jose et al.attitude of college students towards alcohol consumption in mangalore,nujhs vol. 5, no.1, march 2015,issn 2249-7110.

[2] Positive future by Simon Talbot and Prof.Tim Crabbe, Substance page 2

[3] Sukhwal, M \&Suman, L.N. Alcohol related beliefs among college students. Indian Journal of Clinical Psychology. 2008; 35:138-146. 